This is an Accepted Manuscript of an article published by Taylor \& Francis in British Journal of Religious Education on [11/07/2018], available online: http://www.tandfonline.com/ [https://doi.org/10.1080/01416200.2018.1493272].

\title{
A new dialogue between biblical scholarship and Religious Education
}

\section{Susan Docherty, Newman University Birmingham}

Corresponding author: S.E.Docherty@newman.ac.uk

\begin{abstract}
Religious Education (RE) naturally draws on various aspects of the academic study of religions to ensure the accuracy and currency of its content and pedagogy. This paper sets out the case for a more intense dialogue between RE and the field of biblical studies, in order to address perceived weaknesses in the teaching of Christianity in UK schools, specifically in the use of biblical material in the classroom. Two recent major shifts within biblical scholarship are highlighted here: (1) a transformation in the understanding of the first century Jewish context within which Christianity was formed; and (2) the emergence of new forms of biblical interpretation which draw on the perspectives of previously marginalised groups. These developments potentially have important and positive implications for $R E$, because they demonstrate the breadth and variety of the religions of early Judaism and Christianity; offer new information about central topics on current RE syllabi; raise questions about the plurality and 'ownership' of the interpretation of sacred texts; encourage greater nuance in applying biblical texts to contemporary theological and ethical debates; and provide space for people from varied backgrounds to engage directly with the biblical texts in informed and innovative ways.
\end{abstract}

\section{Keywords}

bible; Christianity; Judaism; plurality of interpretation 


\section{Introduction}

Religious Education in the UK has always been open to the insights of other related disciplines. Perhaps the clearest historic example of this positive engagement with the academic study of religion is the transforming effect on syllabi and pedagogy in the latter decades of the twentieth century of Ninian Smart's phenomenological approach (e.g. Smart 1966 and 1988). This paper sets out the case for a new dialogue of a similar kind, between RE practitioners and biblical scholarship. It is important to be clear from the outset what kind of exchange of ideas is being proposed here. This suggestion is not linked to any call for a return to an unduly privileged place for Christianity or 'bible knowledge' within RE, or for an emphasis on 'biblical literacy' as a tool for understanding Britain's cultural heritage. Rather, as a biblical scholar with a professional interest in educating future RE teachers, I aim to promote a genuine conversation by, first, highlighting some very significant recent developments in academic biblical studies which have not yet fully filtered through to those working in $\mathrm{RE}$, although they are beginning to impact on the position of major Christian denominations (see e.g. Pontifical Biblical Commission 1993; Church of England 2014). Second, I envisage this interchange as being mutually beneficial, so that contemporary British biblical commentary can be informed and continually refreshed by the real-life responses of pupils and teachers to these ancient texts and to modern methods of interpreting them.

This call for a more serious dialogue is particularly opportune for two reasons. First, weaknesses are being identified by both examiners and religious educationalists in the ability of students to understand and interpret biblical texts (e.g. AQA 2014, 4; Horrell and Davis 2014), and these problems are now regarded by some (e.g. Bowie 2018) as becoming critical. Second, the recent reforms to GSCE RS in England and Wales have placed greater emphasis on the study of sacred texts and other sources of authority within religions (DfE 2015, 3-6), so developments in biblical scholarship may offer something valuable to teachers and policy makers at this time. Two paradigm shifts in particular have revolutionised biblical scholarship since the 1980s: a new appreciation of the nature of first century Judaism and of the common roots of Judaism and Christianity; and the deliberate inclusion of voices 
other than the professional (and usually white, western and male) interpreter in debates about the meaning of biblical texts. In what follows, then, I shall consider both of these developments and their potential implications for the teaching of RE in schools.

\section{Common roots of Judaism and Christianity}

The first of these far-reaching shifts in understanding owes much to the pioneering work of the American biblical commentator Ed Parish Sanders. In a series of studies (see specially Sanders 1977, 1985, 1994), he subjected the extant Jewish writings dating from approximately $300 \mathrm{BCE}$ to $100 \mathrm{CE}$ to a detailed re-examination which persuasively demonstrated the breadth of thought and practice acceptable among Jews in this period. This enabled him to locate the 'founders' of Christianity, Jesus and Paul, firmly within this religious context. He thus interpreted their teachings, as they are recorded in the New Testament, against the backdrop of first century internal Jewish debates attested in this literature about issues such as, for example, the role of the Temple, the character of the covenant people, and eschatological redemption. Sanders' conclusions pose an irreversible challenge to the long-held (and, as subsequent history has proved, unfortunately all-too dangerous in their consequences) assumptions that early Judaism was a narrow and legalistic form of religion, diametrically opposed to the early Christian message of grace and mercy. This understanding of the textual evidence has since been widely accepted within biblical scholarship, which now recognises, therefore, that the Jesus movement was an integral part of the world of early Judaism, and that the writings collected in the New Testament have to be read as essentially Jewish texts:

A crucial step forward will be taken when Christian scholars recognise that the beginnings of Christianity cannot be understood without reference to Jewish documents and traditions from the late Second Temple period; and when Jewish scholars recognise that the bulk of the New Testament writings are also Jewish documents and that many of them have a right to be counted as witnesses to the breadth and character of Second Temple Judaism... (Dunn 1991, 251). 
At the same time as Sanders was writing, the extent of the diversity of Jewish thought in the centuries immediately before the birth of Jesus was also being corroborated from other sources. A large cache of manuscripts, hidden for almost two millennia, was discovered in 1946 in caves on the shores of the Dead Sea, and these fragmentary scrolls were gradually translated and published during the second half of the twentieth century. They, too, confirm that theological ideas and practices which had long been thought of as innovations of Jesus and his followers were, in fact, shared with other contemporary Jews. This Qumran community, for example, held their possessions in common (1QS VI, 18-22; cf. Acts 4:32-5:11); celebrated a communal meal in expectation of the coming of the messiah (1QSa II, 18-20; cf. Mark 14:22-25 and synoptic parallels); and understood themselves as the true Israel chosen to inherit the new covenant of grace (1QS I, 7; CD VI, 19; VIII, 21; cf. Romans 11:1-6).

This appreciation of the history and traditions which Christians share with Jews clearly has profound implications for inter-faith dialogue, and it is encouraging to see that this new spirit is beginning to be reflected in church documents, such as the recent statement produced by the Vatican Commission for Religious Relations With the Jews (2015). It has not yet impacted to any significant degree, however, on the RE syllabi and text-books in use in the UK, so that misleading impressions may continue to be passed on about both the origins of Christianity and about the nature and development of Jewish religion.

The topic of messianic expectation may serve as one illustration of how this aspect of contemporary biblical studies could inform RE programmes. The traditional explanation for the failure to recognise Jesus as the messiah in his own lifetime is that he did not fit the expected model of a Davidic warrior king, but came either as a 'suffering servant' and/or a divine figure. In the light of modern scholarship, this explanation appears overly-simplistic and even mistaken. It persists, however, despite a wealth of data revealing the great diversity of messianic expectation which characterised first century Judaism (see e.g. Docherty 2018). Students would gain a 
more accurate picture of early Judaism, early Christianity, the New Testament, and the person of Jesus, then, if they were exposed to these surviving Jewish texts, which do not all focus on the messiah's Davidic lineage. Some express a hope for a priestly messiah, for example:

And then the Lord will raise up a new priest to whom all the words of the Lord will be revealed... In his priesthood sin shall cease and righteous men shall find rest in him... (Testament of Levi 18:1-14; translation Charlesworth 1983, 794).

The Dead Sea Scrolls reveal that some Jews expected more than one messiah (e.g. (1QS IX, 11), and they also include a description of a future 'anointed one' who will set people free from illness, oppression and death, and who, therefore looks remarkably like the Jesus of the gospels:

... his anointed one... will honour the pious upon the throne of an eternal kingdom, freeing prisoners, giving sight to the blind, straightening out the twisted... he will heal the badly wounded and will make the dead live, he will proclaim the good news to the poor... (4Q521 II, 7-12; translation Garcia Martinez and Tigchelaar 1998, 1045; cf. Matthew 11:2-6; Luke 7:18-23; cf. Isaiah $29: 18 ; 35: 5-6 ; 61: 1)$.

Another late first century text even uses the title 'son of man' for the awaited future saviour, picturing him as righteous, a 'light for the gentiles', pre-existent, and deserving of worship:

This is the Son of Man... with whom righteousness dwells... [He] is the one who would remove the kings and the mighty ones from their comfortable seats and the strong ones from their thrones... before the creation of the sun and moon, before the creation of the stars, he was given a name in the presence of the Lord of the Spirits. He will become a staff for the righteous ones in order that they may lean on him and not fall. He is the light of the gentiles and he will become the hope of those who are sick in their hearts. All those who dwell upon the earth 
shall fall and worship before him... they will be saved in his name and it is his good pleasure that they have life (1 Enoch 46:3-48:10; cf. 62:7; 63:11; 70:1; 71:14, 17; translation Charlesworth 1983, 34-35).

The term 'son of man' is not then, as has long been taught, unique to the New Testament gospels, so textbooks and syllabi may need to be adjusted to accurately reflect this new understanding of how Jesus fits into the thought patterns of early Judaism.

\section{Variety and development within religions}

This first paradigm shift involves, then, paying greater attention than in the past to the surviving literature from outside the 'canon' of writings which forms the standard bible. Religious ideas and practices which may well have been widespread in early Judaism and Christianity are represented in both surviving liturgical texts like prayers, and in works produced by religious leaders and communities which did not ultimately gain official acceptance as 'scriptural'. Since there is evidence, however, that some of these enjoyed considerable status and authority in many places for several centuries, and that political and social factors as well as religious reasons played a part in their exclusion from the canon (McDonald 2017), they remain important witnesses to the historical evolution of Judaism and Christianity, and to the breadth of thought encompassed within their early forms. Many University biblical studies courses do now routinely include study of these extra-canonical writings to provide a wider context for both the Old Testament/Hebrew Bible and the New Testament, and they are widely available in edited collections and on the internet (see further e.g. Docherty 2014). An already overloaded curriculum and timetable pressures make extensive engagement with this literature impossible within RE lessons, but some awareness of it could provide stimulating new angles on theological issues widely covered in current syllabi.

One topic may again serve to exemplify this claim. The problem of evil is a popular subject in schools, and students are generally introduced to the solutions 
proposed by ancient Greek philosophers and/or to traditional Christian theories centring on the 'fall' of Adam and original sin. However, long before the birth of Jesus, Jewish thinkers were also wrestling with the task of explaining innocent human suffering, and trying to help their contemporaries make sense of various national catastrophes, especially the destruction of the Jerusalem Temple by the Romans in 70 CE. Several early Jewish writings propose theodicies, therefore, which make for interesting comparisons with the more familiar models.

A particularly significant example of an alternative narrative of the origins of evil is to be found in 1 Enoch. Although not included in the canon of either Judaism or the majority of Christian churches, this text was highly influential for several centuries. Copies of it were found among the Dead Sea Scrolls, for example; it is quoted as authoritative in the New Testament Letter of Jude (14-15) and by church fathers such as Origen and Tertullian; and it is even today regarded as scripture in the Ethiopian Orthodox Church. The oldest section of this composite work, called the Book of the Watchers (chapters 1-36), was actually written before the later books of the Old Testament, and in these chapters, wrongdoing and the disorder of creation are attributed not to the disobedience of Adam, but to an angelic rebellion against God. The story of the coming to earth of heavenly beings who mate with human women, known also from Genesis 6:1-4, is told here in a much more elaborate form (1 Enoch 6:1-10:22). It is these fallen angels or 'watchers' who are accused of leading human beings astray, by teaching them all kinds of things which God did not intend them to know, such as how to make weapons of war (1 Enoch 6:1-8:3). Even when God intervenes to remove these disobedient angels from the earth (1 Enoch 10:4-15), demons emerge from their bodies so wickedness remains at large (1 Enoch 15:9-12). Sin and evil has a supernatural rather than a human origin in this account, and there is no focus on Adam's actions. Theological speculation about the fall and its effects must have either started later than the time at which the Book of the Watchers was produced, then, or emerged from within circles of Judaism different from those reflected in the Enochic literature. 
Other Jewish writings from the first century CE provide further evidence of alternative theodicies, and of contested interpretations of scriptural texts, and it is in this context that passages in Paul's letters which which have provided the biblical basis for Christian teaching on original sin should be read. The key verses are these:

Therefore, just as sin came into the world through one man, and death came through sin, and so death spread to all because all have sinned... (Romans 5:12).

... for as all die in Adam, so all will be made alive in Christ (1 Corinthians 15:22).

Paul was not the only late first century Jewish teacher deliberating about the long-term consequences for humanity of Adam's primordial sin, however. The author of a text called 4 Ezra, for example, written in the aftermath of the shattering fall of Jerusalem to the Romans, also attributes responsibility for the current situation of suffering and alienation from God to Adam:

For the first Adam, burdened with an evil heart, transgressed and was overcome, as were also all who were descended from him. Thus the disease became permanent... (4 Ezra 3:20-22; translation Charlesworth 1983, 529).

O Adam, what have you done? For though it was you who sinned, the fall was not yours alone, but ours also who are your descendants (4 Ezra 7:118; translation Charlesworth 1983, 541).

This view is, however, directly opposed in another text from this period. Perhaps fearing that Ezra's position might lead to fatalism or inaction, the author of 2 Baruch argues that, while death may have entered into the human condition through Adam, sin remains a matter of ongoing individual decision and accountability and cannot be inherited:

For, although Adam sinned first and has brought death upon all who were in his 
own time, yet each of them who has been born from him has prepared for himself the coming torment. And further, each of them has chosen for himself the coming glory... Adam is, therefore, not the cause, except only for himself, but each of us has become our own Adam (2 Baruch 54:15, 19; translation Charlesworth 1983, 640).

It seems probable, then, that Paul's influential interpretation of the Genesis narrative emerged from within this lively contemporary theological debate.

The biblical writing which most famously tackles the problem of undeserved suffering is, of course, the Book of Job. Jewish interpreters throughout the centuries continued to reflect on this narrative and to develop it in innovative directions. In a text composed around the turn of the era called the Testament of Job, for instance, Job is pictured looking back on his life before he dies and using his experience to instruct his children. The sufferings he endured are greatly exaggerated in this often humorous retelling - he is said to have ended up living on a dung heap (Testament of Job 20:7), for example, dependent for food only on what his wife can earn from working as a servant, or on the scraps of bread she is able to beg (Testament of Job $21: 2-3 ; 22: 3)$. In this account, however, Job is not presented as a passive victim of satan's games, as he may appear in scripture, but, rather, as a man who actively takes on the power of the devil, in the full knowledge of what it will cost him. His troubles are explained, for instance, as a direct result of his decision to destroy an idolatrous temple even though he is warned beforehand of the dangers of this course of action:

Thus says the Lord: If you attempt to purge the place of Satan, he will rise up against you with wrath for battle.... He will bring on you many plagues, he will take away for himself your goods, he will carry off your children. But ... you will be like a sparring athlete, both enduring pains and wining the crown... ( Testament of Job 4:3-11; translation Charlesworth 1983, 841). 
Throughout this text, God is shown as ultimately in control of the powers of evil, and as present with people in difficult times. Job's response to his trials, and his eventual restoration to happiness in the bosom of his family, teaches that the sufferings of all human life, if borne bravely and steadfastly, are ultimately redemptive.

The early post-biblical Jewish teaching on suffering and evil is very rich and varied then, and might be used to complement study of philosophical texts, to highlight the multiple strands of thought on any issue which are present within every religious tradition, and to emphasise the gradual development of theology as ongoing reflection on authoritative texts generates new interpretations. This picture of the evolving and pluriform nature of all religions serves as an important counterbalance to fundamentalist mind-sets which are reluctant to acknowledge change and diversity within belief-systems.

\section{Plurality of interpretation}

The fact that ancient religious teachers and communities disagreed about the meaning of their sacred texts is evident within the canonical scriptures themselves, as well as in the wider body of early Jewish and early Christian literature. This serves as a strong caution against literal or overly-simplistic readings of the biblical texts, and against any form of 'proof-texting', in which individual verses are culled from different sections of the bible to support a particular position. Some RE textbooks are perhaps inadvertently perpetuating such an atomistic approach by pointing to brief quotations as the supposed scriptural justification for the theological or ethical topic under discussion. The current renewed emphasis on the sources of religious belief is, of course, welcome, but Holm's warning remains valid that within thematic units of RE schemes there is a tendency to detach biblical verses from their context and to ignore

... the nature of the literature, the period when it was written, the purpose it originally served, or the way in which it [is] now interpreted in the religious community... (Holm 1983, 95). 
Greater nuance in using complex biblical material is needed then. For example, there simply is no straightforward answer to a pressing social question like 'What does the bible say about the issue of migration?' Within the Hebrew Bible several different - and even contradictory - positions are expressed about the welcome and treatment which immigrants or 'resident aliens' should receive in Israel. Some writers encourage generosity to them, but do not challenge the assumption that their status in society will be poor and landless:

When you reap your harvest in your field and forget a sheaf in the field, you shall not go back to get it; it shall be left for the alien, the orphan, and the widow, so that the Lord your God may bless you in all your undertakings... (Deuteronomy 24:19-20; cf. 10:18-19; 14:28-29; 26:12-13; 27:20; cf. Leviticus 19:9-10; 23:22).

Other texts advocate a greater equality before the law for immigrants:

So you shall divide this land among you according to the tribes of Israel. You shall allot it as an inheritance for yourselves and for the aliens who reside among you and have begotten children among you. They shall be to you as citizens of Israel... (Ezekiel 47:21-23).

It cannot, however, be overlooked that still other passages imply that migrants can legitimately be used to provide the slave labour necessary to build a new temple in Jerusalem:

Then Solomon took a census of all the aliens who were residing in the land of Israel, after the census that his father David had taken; and there were found to be one hundred and fifty-three thousand six hundred. Seventy thousand of them he assigned as labourers, eighty thousand as stonecutters in the hill country, and three thousand six hundred as overseers to make the people work. Solomon began to build the house of the Lord in Jerusalem on Mount Moriah... ( 2 Chronicles 2:17-3:1). 
These various attitudes are all mirrored in contemporary discourse about immigration, and reflect diverse historical and social circumstances, together with a range of interpretations of Jewish law and tradition. The scriptural texts reveal glimpses of memories of Israel's own nomadic origins, for instance, propaganda in support of the colonisation of the land of Canaan, and a fear of foreign influences among the exiles returning from Babylon to re-settle their ancestral land. Biblical scholarship always looks to recover the distinct contexts which have shaped passages such as these. This makes it an invaluable conversation partner for teachers in the classroom, who, in presenting such texts to students, should help them to recognise their diversity and not shy away from questions about their morality and ongoing relevance. A recent study of the use of biblical material within current GCSE and A Level RS syllabi makes the case for precisely this approach:

RE runs the risk of reducing biblical texts to points of reference that support some aspect of Christian belief, without inviting consideration of the diversity of contemporary Christian perspectives and the extent to which that diversity stems in part precisely from different (often competing) interpretations of biblical texts (Horrell and Davis 2014, 76-77; cf. Bowie 2018).

This plurality of interpretation is fully acknowledged within Jewish sources such as the rabbinic midrashim, produced in the early centuries $\mathrm{CE}$, in which the comments of a number of different rabbis on a scriptural passage are collected and recorded, often without seeking to adjudicate between them. This shows a deliberate intent to preserve all the possible meanings of a text, so that they can inform future reflection on it. Similarly, the fact that Mark's Gospel is widely recognised as a major source for Matthew, demonstrates, first, that this later author regarded Mark's account as being in need of revision, correction or supplementation, and, second, that the early Christian community decided to include both versions of Jesus' life (plus two others) within the canon, rather than choosing between them, thereby retaining multiple readings of Jesus' significance, all of which have some 
validity. It is this multi-faceted nature of the bible which RE syllabi need to strive also to mirror, as far as possible.

\section{Voices from the margins and global perspectives}

A consequence of the first paradigm shift in biblical studies discussed thus far, then, has been an appreciation of the breadth and diversity of the early Jewish matrix from which Christianity emerged. The second is equally concerned with highlighting multiformity, but with a focus on modern perspectives on the texts. As part of wider movements within both the academic study of theology and society at large, the value of contextual readings of the bible is now being emphasised. Such approaches foreground the insights of groups who have generally been excluded from formal interpretative circles, particularly women, people of colour, and those living in the Global South. One of the best-known examples of this contextual methodology in action is a Latin American collection of reflections on the gospels (Cardenal 2010). Inspired by the liberation theology movement, Ernesto Cardenal, a Roman Catholic priest working in Solentiname, a poor and remote part of Nicaragua, during the Somoza dictatorship and civil war, replaced the sermon at his weekly Sunday liturgies with a congregational discussion of the gospel readings of the day. The peasant farmers and fishermen who attended these services brought to the texts their own experiences of poverty, isolation and violence, as well as, in many cases, an avowed commitment to Marxism. Cardenal recorded and subsequently published their dialogues, and a flavour of the way in which the participants related the New Testament passages to their own situation can be seen in the quotation below:

On the prologue to the fourth gospel, John 1:3

The worker is the image of God and everything he produces is good. It enriches man.... The workers continue the power of God on earth by working on creation. That's why the workers should be the owners of the earth and not the ones who don't do any work - the ones who have shoes and food and clothing and travel everywhere and don't work or sow or produce anything... (Cardenal 2010, 3-4). 
The reflections of the community at Solentiname are interesting in themselves, and, furthermore, they illuminate the priorities and theology of 'World Christianity', or the religion as it is expressed beyond the shores of Europe. This is in fact where the majority of Christians now live, but their perspective is often under-represented in the study of Christianity in schools. Considering interpretations like these within $\mathrm{RE}$, alongside more traditional commentaries, thus provides a fuller picture of contemporary Christian uses of the bible, and may also help students to view the gospels differently, as texts which can generate multiple readings, rather than as ancient books with one fixed meaning which can be discovered and communicated only by an educated elite. That in turn raises questions which are central for the study of religions, about who has the authority to explain sacred texts, and about whether all interpretations of them are equally valid.

This shift to draw in previously neglected interpretative voices has recently taken a particularly interesting direction in the UK and North America, where some scholars are beginning to focus on how differently-abled readers engage with the bible. They point to the dangers inherent in traditional commentary of either objectifying disabled people, as if their only function in a gospel narrative (and so in the world) is to be cured, or of implicitly devaluing their experience by glibly assuming that they were all simply grateful to have been given the chance of a 'normal' life through their encounter with Jesus. A more positive reading of the gospels reveals, however, that blind characters like Bartimaeus (Mark 10:46-52; cf. Luke 18:35-43) often have a deeper understanding of who Jesus really is than the majority of their sighted contemporaries (Melcher, Parson and Yong 2017, 295, 321; see also Hull 2001). Intentionally applying the lens of disability to the bible can, then, produce new and more empathetic understandings of the texts, prompt important questions about the attitudes of religious communities towards those classed as disabled, and contribute to wider debates about inclusion in society.

\section{Empowering the reader}


Interpretative approaches which have arisen within liberation theology, or are rooted in specifically disabled or feminist experiences, are all examples of ideological readings, which consciously set out to bring a particular (and usually previously neglected) viewpoint to bear on biblical texts. Other contemporary methods of biblical scholarship are not as intentionally committed in their perspective, but they do share a common aim of empowering a variety of readers. I shall highlight two of these approaches, which offer a way of responding to the fact that many Europeans who encounter the bible today (including young people in schools) will have little prior knowledge of its contents or its history of interpretation, and no investment in at as a sacred or revelatory text (see e.g. Pietersen 2011).

The first is narrative criticism, a method which has steadily gained influence within biblical studies since the 1980s. It starts from the premise that, since the bible is fundamentally a work of literature, the tools which are routinely applied to many other writings can fruitfully be brought to bear on it, such as critical analysis of structure, plot, characterisation, vocabulary and so on. The growing importance of this approach has been formally recognised within the Christian churches, and its potential to enrich critical study of the bible has been specifically commended by the Pontifical Biblical Commission (1993, Section IB). Its usefulness for RE lies in the fact that it invites people of all different religious persuasions and none to respond to the biblical texts without preconceptions, just as they would to any other narrative, thereby making them more accessible to a wider audience.

Several introductory level books are now available which include both an explanation of literary criticism and worked examples of its application to biblical passages. Weren's narrative analysis of the account of the raising of Lazarus (John 10:40-11:54), for example, reveals that although Martha is often compared unfavourably to her sister Mary in traditional interpretation, on close reading it transpires that she is in fact depicted here as possessing attributes required of a disciple of Jesus, such as independence, enterprise and readiness for action (Weren 1999, 66-72). Perhaps even more important than these new insights into individual narratives, however, is the way in which this method could be employed to help 
overcome the current problem of students encountering the bible as isolated fragments, rather than reading passages as literary and theological 'wholes'.

The second noteworthy approach is exemplified by the work of Symon Hill, who seeks to engage readers from outside the churches with the bible. In his most recent book (Hill 2015), for instance, he describes how he invited a group of sex workers to discuss Jesus' teaching on sex and prostitutes, specifically his warning to the chief priests and Jewish elders:

Truly I tell you, the tax-collectors and the prostitutes are going into the kingdom of God ahead of you (Matthew 21:31).

One of these women responded by asking whether Jesus expected the prostitutes to give up their sex work (and thus perhaps their only means of earning income) if they were to become his followers and gain entrance to his kingdom of God (Hill 2015, 114). Traditional Christian interpretation assumes that a complete break with a 'sinful' past is indeed demanded in passages like this, but, in fact, as Hill's questioner realised, this is not stated explicitly in the text. In another challenge to commonlyheld assumptions, Hill's groups of unchurched readers mostly reacted with genuine shock when he explained that the 'king' in the Lukan Parable of the Talents (Luke 19:12-27) is generally understood by Christians as representing God: they had regarded this figure as a cruel bully who must surely be the 'baddie' of the story (Hill 2015, 37-42). These striking insights demonstrate the importance to both sides, then, of genuine dialogue between biblical scholars and lay readers of all backgrounds.

\section{Conclusions}

This paper has outlined two significant developments in twentieth century biblical studies, and argued that they have potential implications for the teaching of RE. First, a case has been made for more account to be taken of the extra-canonical literature which has come to the forefront of academic biblical studies in recent 
years. These writings provide essential information about the common thoughtworld of early Judaism and early Christianity. The depth and diversity of these religions is often not sufficiently brought to the surface in current syllabi and textbooks, as was illustrated by considering the topics of messianic expectation and sin and suffering. Engagement with this material is necessary if students are to acquire through their RE lessons an accurate understanding of the religions of Judaism and Christianity, of their historical evolution, and of the close relationship between them. This sensitivity to their shared history is a pre-requisite for inter-faith dialogue on an Institutional level, and also for efforts to combat anti-Semitism as it continues to be experienced in society and reinforced in some online sources.

Second, greater use might be made of modern interpretative methods such as literary and contextual criticism. These are accessible because they allow people of all different religious persuasions and none to respond to the biblical texts without any preconceptions about their status as divine revelation, and without lengthy previous study. They can help to address perceived weaknesses in current use of biblical material in school RE by fostering a greater understanding of biblical passages as literary wholes, a deeper appreciation of the pluriformity of perspectives present both within biblical texts themselves and among commentators, and a consequently far more nuanced application of them to contemporary theological and ethical issues. As recognised in some recent curriculum reform (e.g. Pett 2016), all this is vital if students are to be helped to move beyond a fundamentalist approach to the interpretation of sacred texts, or to see them as anything other than fragmentary sayings introduced to 'prove' arguments within pre-determined topics with which they may have little genuine connection. By drawing in voices which have been unheard in the past, and by emphasising the multi-faceted nature of the bible, current biblical scholarship can thus aid teachers in leading students to a better understanding of what the bible is, and of how it actually functions within believing communities today.

\section{References}


AQA. 2014. Religious Studies 40553: Report on the Examination. Manchester, AQA. Bible, New Revised Standard Version.

Bowie, R. 2018. "Interpreting Texts More Wisely: A Review of Research and the Case for Change in English Religious Education." In Christian Faith, Formation and Education, edited by John Shortt and Ros Stuart-Buttle, 211-228. Cham: Palgrave Macmillan.

Cardenal, Ernesto. 2010. The Gospel in Solentiname. New York: Orbis.

Charlesworth, James H. 1983. The Old Testament Pseudepigrapha. Volume 1. New York: Doubleday.

Church of England Archbishops' Council Education Division and the National Society. 2014. Making a Difference? A Review of Religious Education in English Schools (online). Available at: https://www.churchofengland.org/sites/default/files/201710/2014_making_a_difference_a_review_of_religious_education_in_church_of_e ngland_schools_web_final.pdf (accessed 4th March 2018).

DfE. 2015. Religious Studies GCSE Subject Content. London: Crown.

Docherty, Susan E. 2014. The Jewish Pseudepigrapha: An Introduction to the Literature of the Second Temple Period. London: SPCK.

Docherty, Susan E. Forthcoming. "Scripture and Religious Education: Jesus as 'Messiah' and 'Divine Son' - Insights from Recent New Testament Scholarship." In Religious Education in Catholic Schools: Perspectives from Ireland and the UK, edited by Sean Whittle. Oxford: Peter Lang.

Dunn, James D.G. 1991. The Partings of the Ways Between Christianity and Judaism and Their Significance for the Character of Christianity. London: SCM.

Garcia Martinez, Florentino and Eibert J.C. Tigchelaar. 1998. The Dead Sea Scrolls Study Edition. Volume 2. Leiden: Brill/Grand Rapids, Michigan: Eerdmans.

Hill, Symon. 2015 An Upside Down Bible: What Jesus Really Said About Money, Sex and Violence. London: Darton, Longman \& Todd.

Holm, J. 1983. Teaching Religion in School: A Practical Approach. London: Oxford University Press.

Horrell, D. and Davis, A. 2014. "Engaging the Bible in GCSE and A Level Religious Studies: Environmental Stewardship as a Test Case." British Journal of Religious Education, 36(1), 72-87. 
Hull, John. 2001. In the Beginning There Was Darkness: A Blind Person's Conversations With the Bible. London: SCM.

McDonald, Lee. M. 2017. The Formation of the Biblical Canon. 2 volumes. London: T\&T Clark.

Melchar, Sarah J., Parsons, Mikael C. and Yong, Amos (eds.). 2017. The Bible and Disability: A Commentary. Waco, Texas: Baylor University Press.

Pett, S., ed. 2016. Understanding Christianity: Teacher's Handbook. Birmingham: Christian Education Publications.

Pietersen, Lloyd. 2011. Reading the Bible after Christendom. Milton Keynes: Paternoster.

Pontifical Biblical Commission. 1993. The Interpretation of the Bible in the Church. Address of His Holiness John Paul II and Document of the Pontifical Biblical Commission. Rome: Libreria Editrice Vaticana.

Sanders, E.P. 1977. Paul and Palestinian Judaism: A Comparison of Patterns of Religion. Philadelphia: Fortress.

Sanders, E.P. 1985. Jesus and Judaism. London: SCM.

Sanders, E.P. 1994. Judaism Practice and Belief 63BCE $-66 C E .2^{\text {nd }}$ edn. London: SCM.

Smart, Ninian. 1966. The Teacher and Christian Belief. London: Clarke.

Smart, Ninian. 1998. Dimensions of the Sacred: An Anatomy of the World's Beliefs. Berkeley: University of California Press.

Vatican Commission for Religious Relations with the Jews. 2015. The Gifts and Calling of God are Irrevocable. Available online at http://www.vatican.va/roman_curia/pontifical_councils/chrstuni/relations-jewsdocs/rc_pc_chrstuni_doc_20151210_ebraismo-nostra-aetate_en.html (accessed 20th January 2018).

Weren, Wim. 1999. Windows on Jesus: Methods in Gospel Exegesis. London: SCM. 